a poem

w/ self-service.

Give me another brick.

Translated by Stavros Deligiorgis

TAMURA RYUICHI / JAPAN

\title{
Four Thousand Days and Nights
}

For the birth of one poem

we must kill

we must kill many

we must shoot, assassinate, poison many beloved.

Look,

simply because we wanted the trembling tongue of a small bird

from four thousand days and nights

we shot the silences of four thousand nights and

the backlight of four thousand days.

\section{Listen,}

simply because we wanted the tears of a starving child

in all the rainy cities, the smelting furnaces and

midsummer wharves and coal mines

we assassinated the love of four thousand days

and the pity of four thousand nights.

Bear it in mind,

because we wanted the fear of a stray dog

who sees what we cannot see

who hears what we cannot hear

we poisoned the imagination of four thousand nights and

chilly memories of four thousand days.

To give birth to one poem 
we must kill our beloved.

This is the only way to resurrect the dead, the way we must take.

\section{World Without Words}

1 The world without words is a sphere at noon I am vertical

The world without words is poetry at noon I cannot stay horizontal

2 I will discover the world without words with words I will discover a sphere at noon, poetry at noon I am vertical

I cannot stay horizontal

3 June midday

The sun was above my head

I was among many rocks

Then

the rocks were a corpse:

the lava corpse of

the energy of

volcanic explosion

Why at this moment

are all forms a corpse of energy?

Why at this moment

are all colors and rhythms the corpse of energy?

A bird,

for instance, an eagle

in its slow spiral

observes but does not criticize

Why at this moment does it simply observe the forms of energy?

Why at this moment

does it not criticize every color and rhythm?

The rocks were a corpse

I drank milk and

tore at bread like a grenadier 